\title{
Internet Conceptual Metaphors
}

\author{
Elena N. Galichkina* \\ Astrakhan State University \\ 20a Tatishchev, Astrakhan, 414056, Russia
}

Received 22.04.2015, received in revised form 18.05.2015, accepted 06.01.2016

\begin{abstract}
Although mechanism of metaphoric representations of various conceptual metaphors has been described by the representatives of cognitive semantics, it is still not clear whether people of different nationalities use the same or different metaphors to conceive Internet. The objective of this article is to throw light on what Internet conceptual metaphors are used in English and Russian computer-mediated communication. Moreover, the main focus of the article is to single out central domains used for Internet metaphors. The first section of this paper discusses the problem of metaphorisation. The second part of the article provides the complete description of the mechanism of metaphorical representation of computer-mediated concepts based on American and Russian corpora. A 1500 sentence analysis of the examples collected from the electronic databases American Corpus and Russian Corpus allowed singling out two dominant types of metaphors Internet is conceptualized with.
\end{abstract}

Keywords: computer-mediated communication, Internet conceptual metaphors.

DOI: 10.17516/1997-1370-2016-9-2-470-480.

Research area: philology.

\section{Introduction}

The vision of the world, the means of cognitive development of the surrounding reality and its adequate perception are deeply anthropocentric: a man can not carry out perception without mental operations of comparison, assimilation and finding familiar features that produce metaphors, which help "to obtain new knowledge about the world and add them to verbalization" (Telia 1988: 186). In other words metaphors function as a mechanism for cognitive modeling of reality (Ricoeur 1990: 425), the essence of which consists in the fact that during the development of a new phenomenon, a man forms the concept of this phenomenon by means of already known reality. This mental operation, according to V.N. Telia, “... leaves traces in the metaphorical sense, which in turn is "intertwined" into the picture of the world, expressed by language" (Telia 1988: 187).

The mechanism of metaphoric representations of concepts presents a long interest to different linguists. But the most successful results are achieved by the representatives of cognitive semantics. They interpret a metaphor as the transfer of cognitive structure, prototypically associated with a particular linguistic unit from the content area in which it arose to another area. When the process of metaphorisation is taking place, we

(C) Siberian Federal University. All rights reserved

* Corresponding author E-mail address: elenagalich@rambler.ru 
deal with the projection of one concept sphere onto another. It is a sort of conceptual expansion, resulting in the capture and exploitation of new areas.

Although several researches have been done on conceptual metaphors of the Internet, it is still not clear, if people of different nations use the same or different conceptual metaphors to conceive Internet. So, the main questions I would like to address in this paper are: "Which conceptual metaphors are used to conceptualize English and Russian computermediated communication?", "Which domains are used for Internet metaphors?". By a conceptual metaphor Lakoff and Johnson mean not simply a poetic use of words, but actually thinking and talking about one thing in terms of another. They stated that our speech, thoughts, and actions are based upon metaphors that are entwined in our lives and become invisible. Our ordinary conceptual system, in terms of which we both think and act, is fundamentally metaphorical in nature (Lakoff and Johnson 1980: 3). Being self-fulfilling prophecies (Carter 2005), metaphors help us to understand reality. Therefore, it makes sense to study the metaphorical process taking place in the computer-mediated communication.

The following studies inspired the writer to investigate the topic of conceptual metaphors in the Internet; Zach Tomaszewski conducted a study to investigate two dominant conceptual metaphors of the World Wide Web: social and functional (Tomaszewski, 2002). Rebecca Johnston (2010) examined narratives written in mainstream public forums to find out metaphors of physical space, physical speed, salvation and destruction to describe the Internet. Denis L. Jamet (2010) looked at the most frequently used Internet metaphorical expressions to conceptualize the Internet. $\mathrm{He}$ noticed the recurrent use of metaphorical terms related to the sea, movement and journey and found out the following conceptual metaphors: The Internet is a Walk. Carol G. Lombard conducted a study to explain the occurrence of metaphorical entailments in the terminology used by computer networking professionals in the information technology industry (Carol G Lombard 2005). Vlad Tanasescu (2007) describes the metaphoric process, its spatiotemporal aspects and analyses in the context of the Internet and the spatial characteristics: distance, shape, size, movement, orientation and navigation.

My analysis will rest on the theoretical framework of cognitive linguistics and precisely on Lakoff and Johnson's (1980) and Telia's (1988) works on metaphor. This article examines narratives written in the electronic database "American Corpus" (www.americancorpus.org) and Russian Corpus (www.ruscorpora.ru). All examples will be in italics. A 1500 sentence analysis of examples collected from the aforementioned websites shows that in both English and Russian computer-mediated communication two dominant types of metaphors: spatial and socio-oriented conceptualize the Internet. Spatial metaphors link the human environment and the computer within the time interval of their coexistence. Whereas socio-oriented metaphors combine computers and people in social networking. The following spatial metaphors can be singled out: Internet is a Container, Internet is a Place, Internet is a Surface, Internet is an Ocean, Internet is a Superhighway.

\section{The Internet is a container}

The nature of the first spatial metaphor, Internet is a Container is clear: a man himself is a "container", limited by the body surface and accordingly, he projects his orientation "insideout" to the other physical objects and phenomena (Lakoff, 1980). As a container the Internet stores all sorts of information, text, graphics, 
audio-visual which in turn is extracted directly from it. For example: This could be because the newspaper contains more job information in Hong Kong, while the Internet contains more job information in other countries.

The most commonly used verbs are to download, to find, to get something from the Internet.

The metaphorical model Internet is a Container is also derived from the pattern using a spatial preposition "from". In the following example the preposition from states the original motion, with the Internet being the source and the place whence the action is taking place: Nowadays, the Internet is very common, and the information from the Internet is very up to date. However, the 1500 sentence analysis from electronic databases "American Corpus" (www. americancorpus.org) and Russian Corpus (www. ruscorpora.ru) shows that the preposition from does not state the location of the Internet and its spatial characteristics, closeness or openness remain not stated.

\section{The Internet is a place}

The second spatial metaphor, Internet is a Place compares actions and states in the computer environment with non-network life; thus, we can "enter" this space (to enter the Internet), sell something (to sell smth on the Internet) and do something (to do business on the Web; to work on the Internet). These phrases are related to the Internet in the following way: When you enter the Internet, which is the first site you access?/ Когда вы заходите в Интернет, какой сайт является первым?; If you plan on selling a product online, one of the main things you'll want to focus on is learning how to create a search engine friendly website so people can find your site / Если вы планируете продать продукт в Интернете, одна из главных вещей, на которой вы захотите сосредоточиться - это научиться создавать удобную поисковую систему сайта, чтобы люди могли найти ваш сайт; What laws govern business on the Internet? What kind of lawyer do I need for a legal problem involving the Internet? / Какие законы регулируют бизнес в Интернете? Какой юрист мне нужен для урегулирования юридической проблемы, связанной с Интернетом?

The vastness of the Internet space is frequently annunciated by the verb to roam, which is actualized in the meaning "to wander in any place / space without a purpose» (MED, 2002:1229): Already our children are roaming on the Internet, our academicians are discussing with their colleagues and even teaching students over a global communications network.

\section{The Internet is a surface}

Internet is a Surface conceptualizes the Internet as a surface, which is vast: The Web is a by-product of the Internet, created because of the Internet's overwhelming size. On this "surface" we can see:

- information databases: There is already full e-mail compatibility between different services, and many information databases on the Internet can now be reached by anyone with a commercial network address;

- sites: A handy pull-down menu of bookmarks is great if you visit only $\underline{a}$ dozen sites on the Web. But even the most nerdy of netizens can find a couple hundred intriguing sites that they imagine they'll have time to visit again.

- companies, firms; customers, users: Proprietary on-line services such as CompuServe, America Online and Prodigy will be outnumbered by World Wide Web users on the Internet by the year 2000, says Boston-based Forrester Research; 
- home-pages, blogs, mailboxes, articles, and much more.

The following phrases confirm the vastness of the "surface": there are many good sources on the Internet; many information databases on the Internet; multiple sites on the Internet; vast amount of information on the Internet; lots of pages on the Internet.

Russian users conceptualize the Internet as a vast surface without borders writing about "бескрайние просторы Интернета" / the boundless space of the Internet. These metaphorical phrases are closely connected with Russian mentality, as the territory Russians live on is really big. This feeling serves a starting point for metaphorization:

Путешествуя по бескрайним просторам

Интернета, пользователи выходят $\underline{\mathrm{Ha}}$ просторы Сети для того чтобы расширить свой круг общения;

Как всегда, задолго до начала отпуска, $я$ начал бороздить бескрайние просторь всемирной паутинь с иелью найти как можно больше материала, отвечающего на вопросы «куда» и «как» лучше поехать omdblxamb.

One interesting thing is that Englishlanguage computer-mediated communication is characterized by a more frequent use of the word Internet with the preposition on, whereas in Russian computer-mediated communication the preposition in is more common, as the events are taking place "in the network". Here, we should pay special attention to the following ethnic peculiarities: in English lingvoculture the Internet is more often perceived as a plane surface (on the Internet), whereas in Russian lingvoculture the Internet is more of a closed space (in the Internet):

$$
\begin{aligned}
& \text { - Большая часть пользователей } \\
& \text { приходит в Интернет с иелью } \\
& \text { общения; }
\end{aligned}
$$

- Пришел в Интернет; Приходи вчат;

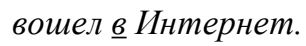

- There are thousands of newsgroups on the Internet, each offering a specialist area in which people can discuss common interests, ask or answer queries and post stories or pictures;

- In 2002 there were approximately 25 Australian-created racist websites on the Internet.

- On one hand, the Internet gives users access to the information on hundreds of thousands of servers throughout the world-the breadth and depth of available knowledge is incredible. On the other hand, the documents on the Internet are "surfable" from a single location, bringing a global library to your computer.

Both in English and Russian, the Internet is represented as a multifunctional surface, a space for private and business communication, recreation and e-commerce.

- Интернет - это новая среда обитания; Она стремительно обживается и приспосабливается для пребывания; Интернет - это среда купли-продажи.

\section{The Internet is an ocean}

Denis L. Jamet (2010) writes that 'American English often uses the source domain of the sea to structure Internet in relation to the first colonists who landed in America and discovered a vast space, an open land before them. The Anglo-Saxon mentality is genetically associated with navigation, so the water metaphor is most common for the English perception of the Net (to surf the Internet, to navigate the Internet, to browse the Internet, to explore the Internet). The often-used verb to surf is in the center of this metaphorical model. According to Macmillan English Dictionary (MEDAL 2002: 1446), the relevant definitions for 'surfing' is to ride on 
waves in the sea on a surf board (to go surfing); to look at various places one after another on the Internet (MEDAL 2002: 1446). The verb "to surf" metaphorically emphasizes the freedom of movement in the boundless virtual environment.

The research demonstrates that the realities describing a man's social existence in real life, such as interest in any kind of sport, for example surfing, serve as a source of metaphorization. "Surfing" on the Internet is described as a journey on the waves of the sea, which requires a certain skill, knowledge, since it can be risky: "Surfing the Internet" is a misleading metaphor. It is really more like "Scuba Diving the Internet ", with all the complexities of equipment, navigation theory, and understanding the wildlife and the terrain. The conceptual metaphor that the Internet is an Ocean is typical of the Englishlanguage computer-mediated communication whereas in the Russian-speaking community, Internet users tend to terms referring to the source domain of the land. Russian users say “бродить по Интернету / to wander in the Internet», «гулять по Интернету, блуждать nо Интернету / to walk in the Internet», underlining the idea of walking without a special purpose.

It is interesting to note that Russian users use the phrase "плыть по волнам Интернета" I to swim over the Internet's waves. Zach Tomaszewski in "Conceptual Metaphors of the World Wide Web" (2002), points out that when surfing, a surfer mostly relies on the waves to carry him forward, though he does have a choice in which wave he catches. In the same way, a Web surfer chooses to follow only one of the links available on a certain page, rather than actively seeking a certain destination. Both types of surfing are passive forms of transportation involving occasional choices and that rely on the nature of medium over which the surfer is travelling. And both must occur in some kind of space.

The use of the structure "to navigate the Internet" underlines the idea of a thoughtful action, movement or displacement for a particular route, which requires knowledge and skills to navigate in a given environment. According to Macmillan English Dictionary and Oxford Advanced Learner's Dictionary (MEDAL 2002: 1446; OALD 1995: 775), the relevant definition for "navigating" is to choose a path so that a ship, plane or car can go in a particular direction, especially by using maps or instruments; to sail along, over or through a sea, river, etc.

The verb "to browse" underlines the idea of aimless wandering in the virtual environment, which according to Macmillan English Dictionary means (computing) to look for information on a computer, especially on the Internet; to look at a website on the Internet: an excellent graphical interface for browsing web pages; to look at things in a shop without being sure whether you want to buy anything: customers are welcome to browse; (+ through) to look at information or pictures in a book of magazine, without looking for anything in particular (MEDAL 2002: 173).

Targeted search for objects in the network is represented metaphorically with two metaphorical models. The first model "to search the Web" is used if there is some information about an object, but a clearer understanding of this object is required: Whether you're a seasoned Internet veteran or a newbie learner, you know how slow it can be to search the Web. The second model "to explore the Internet" it used to nominate the process of finding the unknown object and travelling in order to gain knowledge about the unknown object: At its simplest level, the system will allow you to log on to e-mail networks such as CompuServe or Delphi, and let you explore the Internet or exchange files with other PCs using the modem. 


\section{The Internet - is a superhighway}

In the election program of 1992, Senator Albert Gore popularized the term "Information Superhighway" translating the vision of universal access to a vast matrix of interconnected computer systems. The less popular equivalent "Infobahn", was soon taken from German, where "bahn" means "highway" (Flexner, Soukhanov 1997: 69):

- Millions of people are completely ignoring the information highway. Many years ago few people knew about the Internet or even the Information Superhighway or the Infobahn. Here in Hesperia we don't even have universal cable television and it is the cable industry that will probably provide the infrastructure for the Infobahn.

The metaphor of the Internet as a Superhighway is relevant for the English language computer-mediated communication. Zach Tomaszewski (2002) considers a "superhighway" to be a social metaphor writing that "highways are constructed to get us to a destination. The focus is on speed and direct access rather that on a scenic or enjoyable journey'. The rapid transfer of information on the Internet is correlated with the constant movement of cars on a superhighway, moving in different directions and with different speed:

- The "Information Superhighway" is an appropriate name for the Internet, as the way data travels in networks around the world is comparable to the way cars travel: constantly and in different directions and speeds and with only one objective - to get to it's destination.

The idea of the "general availability" of the Internet is presented in the definition of the term "highway - a road or way on land or water that is open to public use " (AELD 2002: 1069).
Socio-oriented metaphors are based on the idea of combining computers and people in social networking. The following socio-oriented metaphors can be singled out: Internet is a Living Space, Internet is a Global Village, Internet is a Klondike.

\section{The Internet is a living place}

The Internet seems like a great free nation, where institutional relations are irrelevant. On the one hand, there are online resources for the contemporary world: various websites of government institutions, companies, social and cultural institutions, mass media and so on. On the other hand, the Internet is an "agora", or an ancient Greek meeting place, where "inhabitants" are free to speak about any topic.

The socio-oriented metaphor the Internet is a Living Place is supported by the existence of the people who "inhabit" the Net:

- The people on the Internet are not all as highly computer literate as one might think»; «No matter how strange you are, there's someone else just like you among the millions of people on the Internet. And as more and more people hook up to the net, this becomes more and more true.

The special telescopic neologism netizen appeared and refers to the people located in the "habitable space" of the Internet in Englishspeaking computer-mediated communication. "Netizen" is a combination of two words: net and citizen.

The Internet "inhabitants" are demographically differentiated by age and according to gender:

- Different demographic groups have different interests on the Internet. The young like instant messaging and downloading music. Older Internet users are more likely than younger users to get health information and seek material at 
government Web sites. Women are likely to seek information on health or religious topics. Men are more drawn to news, financial information and sports news.

The Internet also becomes a metaphor for contact and communication in general thanks to the following connectors:

1) through; By the way, you could get the 'update' jobs information through Internet»; «Only students will be able to apply for Barclaycards directly through Internet; The Quality Bulletin is also accessible through the Internet under the Hospital Authority homepage;

2) across; Ascend is said to be in an excellent position to extend and integrate its architecture across the Internet;

3) over; Last month, IBM and Equifax said they set a strategic alliance to develop and market services that ensure safe and more secure transactions over the Internet and private computer network systems; Comments and assistance were provided over the Internet and in personal interviews with academics and others around the world; Technology workers, health personnel and people in the arts, media, finance, accounting, and human resources tend to have an easier time finding work over the Internet than others;

4) via; Eve and Simmy met via the Internet and they fell in love; We can strike up friendships or re-establish contact, purely according to the criterion of the things most important to us, via systems such as the Internet; How hard do you think it would be for a complete stranger - or the employee you fired yesterday, or your estranged ex-lover - to find all of your personal information via the Internet?.

\section{The Internet is a global village}

We can point out that the "global village" is a metaphorical hyperbole, in which proximity is interpreted not as a topographical phenomenon, but rather a social, psychological or spiritual one.

- With the rise of the World Wide Web, ordinary people could participate in a real-life 'global village': they could post messages on message boards, and create Web pages proclaiming their interests to the world.

\section{The Internet is a frontier}

The historian Franklin D. Turner in 1893 noticed that a frontier, a movable boundary and "a state of society", significantly contributed to the development of the following distinctive features of U.S. citizens national character: enterprise, individualism, faith in one's own strength, freedom, and focus on success. Alexandr Voiskunsky in his article "Metaphors of the Internet", notes that "electronic frontier" in the figurative sense means "the recruitment of the newcomers (newbies) in the number of supporters of networking technologies, "an escape" from tiresome everyday life into a "cyberspace." This aspect of the Internet was also pointed out by Tomaszewski (2002) in his paper on the 'Conceptual Metaphors of the World Wide Web'. "Progress is often thought of as expansion into new regions: across the continent, off the planet, or into the new cyberspace. When thinking of the Web as a frontier, we think of pioneers facing hardships, preparing the way for those to come. We think of it as a source for new resources. It holds the possibility for a better life than where we currently are."

\section{The Internet is a klondike}

The comparison of the Internet with Klondike in Russian computer-mediated communication is worth mentioning. Klondike is an "incredibly rich field", a place with unimaginable hidden wealth. This metaphor gives a positive view of the 
Internet, offering users opportunities to realize cherished dreams:

- Интернет - Клондайк для всех место, где сбываются все мечты, решаются проблемы, удовлетворяютсяжелания / Internet - is a Klondike for everybody: a place where all dreams come true, all problems are solved and desires satisfied.

In English the Klondike metaphor has yet appeared in other contexts, as a Patience solitaire card game and as a brand name for a dessert generally consisting of a vanilla ice cream square coated with a thin layer of chocolate-flavored coating.

The following metaphors should be also considered as socio-oriented:

The Internet - is a vehicle, denotes the dynamics of intellectual and communicative progress.

- After more than 50 years running international programs, it sees the Internet as the ideal vehicle for linking schools, communities or individual students, and has invested heavily in the technology; Internet is simply a vehicle through which millions communicate freely and openly;

The Internet - is a (re) source underlines the idea of "information richness" to society.

- For any number of historical reasons, the Internet has emerged as a huge, rich source of information accessible only via a series of interfaces;

- After human teachers, the Internet would represent the most important educational resource in the world if every student had a computer.

We should also pay attention to sociooriented metaphors that represent a negative attitude toward globalization of communication in general and Internet-based communication, in particular, as a simulator for real human relationships. The following negative metaphors (as named by Rebecca Johnson, 2010 as metaphors of destruction) were singled out in the Russian computer-mediated communication:

The Internet is a book killer

- В молодости нама семья собирала книги. Мы думали: дети вырастут и передадим драгоченное наследство... Дети выросли, появились внуки, но никому наме богатство не нужно: книги пылятся в шкафах, а внуки часами блуждают в Интернете. Знаю, это проблема не только нашей семьи / In my youth, our family gathered books. We thought, the kids will grow up and we will share these precious presents with them. The boys have grown up and we have become grandparents, but no one needs our wealth. Our books are gathering dust in closets, and our grandchildren spend hours wandering the Internet. I know this is a problem not only for our family;

The Internet is a malfunctioning water pipe

- Интернет на наших глазах превращается в очень мощный универсальный ресурс, который стал доступен практически каждому. Интернет это эдакий водопровод нашего времени, из которого хочешь ведрами, хочешь стаканами черпай информачионно что желаешь, хочешь родниковую воду, а хочешь отходы цивилизаций или ......"вирусы" / Before our eyes the Internet has turned into a very powerful multi-purposeful resource that has become available to almost everyone. The Internet is the water pipe of our time, from which, if you want, 
with buckets or cups you can scoop out the information you desire, or like spring water or the waste of civilizations or ....... «viruses».

The following negative metaphors were singled out in both the Russian and English computer-mediated communication:

The Internet is a drug

- Я эту паутину чертову знаю, читал в газете. Опиум для трудового народа! Это ведь как наркомания, Интернет этот. Засасывает в паутину... / I have heard about this damn web. It is an opium for the working people! It's like a drug addiction, this Internet. You simply can suck into a web;

- Is Internet a drug?

The Internet is a disease

- Вы уже приобрели ту или иную форму Интернет - зависимости болезни, которая является истинным бичом поколения 90-x- 2000x. Посетите Интернет-психолога $и$ если окажется что болезнь зашла слишком далеко, то возможно придется прибегнуть к ампутации модема или обрезанию выделенной линии / You have already got some form of the Internet - addiction; a disease that is the real scourge of generations of 90th $-2000 \mathrm{~s}$. Visit our online psychologist, and if it appears that the disease has gone too far, you may have to resort to the amputation of the modem or a leased line.

- Internet addiction is becoming a disease. Of course it is useful in lot many ways like for knowledge, but nowadays especially teenagers are becoming addicted because of social networks, youtube etc.
The Internet is a nest of terrorism

- Интернет стал идеальным местом и для начинающих террористов. В нем существует масса сайтов, на которых выложена детальная информация о том, как возможно изготовить оружие и взрывчатку из подручных материалов, как их использовать и т.д. В Сети существуют сайты, через которые открыто ведется рекрутирование новых членов Террористических групп. Попытки спецслужб отследить организаторов подобных операций, как правило, безуспешны / The Internet has become an ideal place for the birth of terrorists. It contains various sites with detailed information on how to make a weapon or a bomb using different materials and how to use them. Many Internet sites are used to recruit new members to terrorist groups. The attempts of special services to find the organizers of these sites typically fail.

- As Gabriel Weimann, a professor at Haifa University, demonstrates in this book, the Internet has become a tool of vital importance to terrorists around the world. His eight-year survey of terrorists' use of the Internet found that the 40 organisations designated as active terrorist groups by America's State Department now maintain more than 4,300 websites;

- The attractions of the Internet to terrorists are obvious; it allows for cheap, anonymous, international coordination. More important, it enables terrorists to bypass the mass media and deliver propaganda directly.

Whether by comparison to the drug, book killer or a nest of terrorism, these metaphors 
fit into a larger metaphorical model where the Internet is an Enemy to the humankind.

\section{Conclusion}

The electronic database narratives studied in this analysis offered a glimpse at perspectives on the Internet in American and Russian computer-mediated communication. Although several researches have been done on conceptual metaphors of the Internet, it is still not clear if people of different nations use the same or different conceptual metaphors to conceive Internet.

An analysis of the examples taken from the Russia and American databases reveals a consistency in metaphorical projections from the Human Being domain onto the Internet Environment domain. The study shows that in both English and Russian computer-mediated communication the Internet is conceptualized with two dominant types of metaphors: spatial and socio-oriented. The mechanism of metaphorical representation of computermediated concepts presents a shaped projection of the actual concept sphere to another concept sphere, artificially created by the technological environment, in which the computer is the exhibitor of antroposphere.

In computer-mediated communication the representation of concepts through the global image in cyberspace is implemented through spatial metaphors that connect the human environment and the computer within the time interval of their coexistence. The following spatial metaphors are singled out: Internet is a Container, Internet is a Place, Internet is a Surface, Internet is an Ocean, Internet is a Superhighway. The notion of cyberspace as a habitable environment is represented by socio-oriented metaphors based on the idea of combining computers and people in one living community. The following sociooriented metaphors can be singled out: Internet is a Living Place, Internet is a Global Village, Internet is a Klondike.

\section{References}

American English Learner's dictionary (2002). Richard A. Spears PhD, NTC Publishing Group, 2002. 1089p.

Berg F.S., Soukhanov H. Speaking freely: a guided tour of American English from Plymouth Rock to Silicon valley. New York Oxford, Oxford University Press, 1997. 465p.

Carter D. Living in virtual communities: an ethnography of human relationships in cyberspace. Information, Communication \& Society, 8 (2), 148-167.

Jamet D.L. (2010) What do Internet metaphors reveal about the perception of the Internet? Metaphorik.de, 18 (2), 17-32.

Johnston R. Salvation or destruction: Metaphors of the Internet (2010), Available at http:// firstmonday.org/htbin/cgiwrap/bin/ojs/index.php/fm/article/view/2370/2158 (accessed 01.04.2015).

Lakoff G., Johnson M. Metaphors We Live By. Chicago, The University of Chocago Press, 1990. $256 \mathrm{p}$.

Lombard C.G. (2005) Conceptual metaphors in computer networking terminology. Southern African Linguistics and Applied Language Studies, 23 (2), 177-185.

MEDAL - Macmillan English Dictionary for Advanced Learners (2002). International Student Edition. Macmillan Publishers Limited, 2002. 1692 p.

OALD - Oxford Advanced Learner's Dictionary of current English (1995). Edited by A.S. Hornby, Fifth Edition, Oxford University Press, 1995. 1428 p. 
Ricoeur P. Zhivaia metafora [Live metaphor]. Moscow, Progress, 1990. Pp. 435-455.

Tanasescu V. Spatiotemporal Metaphors and Internet Technologies. United Kingdom, The Open University, 2007, $100 \mathrm{p}$.

Telia V.N. Metafora kak model smyslaproizvodstva i ee ekspressivno-otsenochnaia funktsia [Metaphor as a means of sense creation and its expressive function]. Moscow, 1988. Pp. 33-47.

Tomaszewski Z. Conceptual Metaphors of the World Wide Web” (2011), Available at http://www2. hawaii.edu/ ztomasze/ling440/webmetaphors.html (accessed 01.04.2015).

\title{
Концептуальные метафоры Интернета
}

\section{Е.Н. Галичкина}

Астраханский государственньй университет Россия, 414056, Астрахань, ул. Татищева, 20 а

\begin{abstract}
Несмотря на то что механизм метафорического моделирования действительности посредством кониептуальных метафор был описан представителями когнитивной семантики, по-прежнему не ясно, используют ли люди разных национальностей одни и те же или разные метафоры для концептуализаиии Интернета. Цель данной статьи выявить и описать ключевые метафоры Интернета, которые используются в английской и русской компьютерной коммуникации. В первой части статьи обсуждается проблема метафоризаиии. Во второй части представлено описание механизма метафорической репрезентации концептосферы компьютерной коммуникации на материале Русского национального корпуса и Американского корпуса. Всего проанализировано 1500 примеров. В результате анализа было выделено два типа метафор, формирующих концептосферу сетевой коммуникации.
\end{abstract}

Ключевые слова: компьютерно-опосредованная коммуникачия, концептуальные метафоры Интернета.

Научная специиальность: 10.00.00 - филологические науки. 